\title{
MODEL PERMAINAN TARGET UNTUK MENINGKATKAN KEMAMPUAN KOORDINASI PADA SISWA SEKOLAH DASAR KELAS ATAS
}

\section{TARGET GAME MODEL TO INCREASE THE COORDINATION ABILITY AT ELEMENTARY SCHOOL STUDENT}

\author{
A Sumarsono'a, Syamsudin 1 , AK Hermansyah ${ }^{2}$, dan Iswahyuni ${ }^{3}$ \\ 1 Jurusan Pendidikan Jasmani, Kesehatan dan Rekreasi, Fakultas Keguruan dan Ilmu Pendidikan, \\ Universitas Musamus, Jl. Kamizaun Mopah Lama Merauke-Papua, Indonesia \\ 2 Jurusan Pendidikan Guru Sekolah Dasar, Fakultas Keguruan dan Ilmu Pendidikan, \\ Universitas Musamus, Jl. Kamizaun Mopah Lama Merauke-Papua, Indonesia \\ ${ }^{3}$ SDN Kejapanan 1, Kecamatan Gempol, Kabupaten Pasuruan, Jawa Timur, Indonesia \\ a Korespondensi: Adi Sumarsono, Email: adi@unmus.ac.id
}

(Diterima: 20-09-2018; Ditelaah: 02-10-2018; Disetujui: 18-10-2018)

\begin{abstract}
This study aims to facilitate the theory of the development and growth of children according to their age and physical. The basis of this study is the need for physical education teachers to obtain reference sources in improving the biomotor elements of coordination of upper class elementary school students. This development procedure and research adapts the steps of educational development developed by Dick \& Lou Carey. The development step in this study consisted of seven steps, namely preliminary study, initial drafting, expert validation, trial, validation and subsequent revision of the final product. Instruments in data collection using observation and questionnaire distribution. The effectiveness of the product in this study uses a reference to the effectiveness of product use and suitability of the model and development objectives. The results of this study based on the observations of each game, the average score was in the "good" category. Teachers as product users are on average "good" and according to students as actors the model is in the "very good" category. Products that have been produced are stored in VCD. In one VCD package there is a game model and the composition of activities, equipment and rules of the game that are tailored to the needs of upper class elementary school physical education teachers.
\end{abstract}

Keywords: target game, student coordination.

\begin{abstract}
ABSTRAK
Penelitian ini bertujuan untuk memfasilitasi teori perkembangan dan pertumbuhan anak sesuai dengan umur dan fisiknya. Dasar dari penelitian ini adalah kebutuhan guru pendidikan jasmani untuk mendapatkan sumber referensi dalam meningkatkan unsur biomotor koordinasi siswa Sekolah Dasar kelas atas. Prosedur pengembangan dan penelitian ini mengadaptasi langkah-langkah pengembangan pendidikan yang dikembangkan oleh Dick \& Lou Carey. Langkah pengembangan pada penelitian ini terdiri tujuh langkah, yaitu studi pendahuluan, pembuatan draf awal, validasi ahli, uji coba, validasi dan revisi selanjutnya pembuatan produk final. Instrumen dalam pengumpulan data menggunakan observasi dan penyebaran angket. Adapun efektifitas produk dalam penelitian ini menggunakan acuan efektivitas dari penggunaan produk dan kesesuaian model serta tujuan pengembangan. Hasil penelitian pada hasil observasi dari masing-masing permainan mendapatkan rerata skor dalam kategori "baik". Guru sebagai pengguna produk di rerata "baik" serta menurut siswa sebagai pelaku model masuk dalam kategori "sangat baik". Produk yang telah dihasilkan
\end{abstract}


disimpan dalam bentuk VCD. Dalam satu paket VCD didalamnya terdapat model permainan serta susunan kegiatan, peralatan serta peraturan permainan yang disesuaikan dengan kebutuhan guru pendidikan jasmani sekolah dasar kelas atas.

Kata kunci: koordinasi siswa, permainan target.

Sumarno, A., Syamsudin, Hermansyah, A. K., \& Iswahyuni. (2018). Model Permainan Target untuk Meningkatkan Kemampuan Koordinasi pada Siswa Sekolah Dasar Kelas Atas. Didaktika Tauhidi: Jurnal Pendidikan Guru Sekolah Dasar, 5(2): 135-150.

\section{PENDAHULUAN}

Pemerintah Negara Republik Indonesia berkomitmen meningkatkan Sumber Daya Manusianya. Berbagai cara ditempuh pemerintah guna meningkatkan Sumber Daya Manusianya, salah satu langkah yang ditempuh oleh pemerintah adalah melalui jalur pendidikan. Hal ini mengindikasikan pemerintah menjalankan program UndangUndang No. 20 Tahun 2003 tentang sistem pendidikan Nasional Pasal 1 yang menyatakan bahwa pendidikan adalah usaha sadar dan terencana untuk mewujudkan suasana belajar dan proses pembelajaran agar peserta didik aktif mengembangkan potensi dirinya untuk memiliki kekuatan spiritual keagamaan, pengendalian diri, kepribadian, kecerdasan, ahlak mulia serta keterampilan yang diperlukan dirinya, masyarakat dan negara. Setiap program yang dijalankan pemerintah mempunyai kewajiban harus berimbas pada setiap warga negaranya termasuk pendidikan. Penyelenggaraan pendidikan yang dapat dirasakan oleh semua warga negara merupakan jaminan hak yang harus dipenuhi oleh penyelenggara negara (Sumarsono, 2017).

Pendidikan gerak manusia, khususnya pada lingkup dunia pendidikan masih di andalkan pada materi mata pelajaran pendidikan jasmani. Tujuan yang hendak dicapai dari pendidikan jasmani diantaranya adalah memfasilitasi siswa untuk mencapai dan menunjang perkembangan dan pertumbuhan siswa. Hal ini dapat berupa kemampuan fisik dan motorik, kecepatan berfikir, kemampuan pemecahan masalah serta kecakapan emosional dan sosial. Tujuan yang utama dari program pembelajaran pendidikan jasmani adalah memberikan pengalaman belajar, yang mencakup pengalaman gerak dan pengalaman keberhasilan dari setiap individu siswa. Banyak kalangan pendidikan berpendapat bahwa pendidikan jasmani selain menjadi suatu proses pendidikan umum, juga mempunyai andil yang besar dalam meningkatkan tingkat jasmani yaitu melalui perbendaharaan gerak. Pendapat Sumarsono (2015) Tujuan dari pendidikan jasmani yang sebenarnya bukan terfokus pada seberapa cepat siswa bisa berlari, seberapa jauh dan tinggi siswa dapat melompat, seberapa jauh siswa dapat melempar, serta seberapa tepat siswa dapat menghasilkan tendangan yang masuk kedalam gawang, akan tetapi fokusnya lebih pada pengalaman siswa dalam melaksanakan tugas gerak dan pengalaman berhasil siswa dalam melaksankan tugas gerak. Hal ini mengindikasilkan bahawa apabila seorang mempunyai keterampilan gerak yang baik maka dia mempunyai kesempatan yang besar untuk dapat menguasai keecakapan hidup yang dibutuhkan (Gani, 2016). Untuk itulah kegiatan pendidikan jasmani di sekolah seharusnya di lakukan dengan materi pembelajaran yang menyenangkan. Siswa melakukan tugas gerak tanpa ada paksaan serta malakukannya dengan sukarela. Tugas 
yang tak kalah penting bagi guru pendidikan jasmani adalah membuat dan menyelenggarakan pendidikan jasmani yang beraneka ragam guna mengurangi rasa kebosanan siswa. Hal ini dapat di lakukan dengan media permainan. Melalui permainan dapat digunakan sebagai cara stimulasi gerak siswa dengan permainan yang menantang dan permainan yang baru (Sumarsono, 2017).

Proses pembelajaran pendidikan jasmani yang lebih memfokuskan pada pengalaman gerak siswa. Salah satu faktor pendukung keterampilan gerak siswa adalah kemampuan koordinasi. Koordinasi setiap manusia merupakan bagian dari kemampuan perseptual setiap individu, oleh karena itu harus diajarkan sejak usia dini. Sesuai dengan teori olahraga bahwa faktor koordinasi mempunyai faktor dominan dalam membuat suatu jenis gerak. Sedangkan dalam pendidikan Sekolah Dasar faktor kemampuan koordinasi sebagai salah satu parameter kemampuan motorik setiap siswa, serta merupakan kemampuan yang mendasari dalam belajar berbagai keterampilan gerak (motorik). Anak yang memiliki kemampuan koordinasi baik akan nampak luwes, mudah, dan harmonis dalam melakukan setiap keterampilan motorik.

Guru sebagai salah satu komponen yang bertanggung jawab atas pencapaian pendidikan, keberadaan guru di sekolah sangat menentukan. Guru yang profesional harus mampu melibatkan anak didiknya secara fisik, mental dan emosional dalam pembelajaran. Pembelajaran pada umumnya bertujuan mengembangkan potensi siswa agar dapat tercapainya tujuan yang diharapkan. Pembelajaran pendidikan jasmani di Sekolah khususnya di Sekolah Dasar (SD) saat ini sudah menjadi perhatian banyak kalangan. Mengingat usia siswa dalam masa perkembangan dan masa pertumbuhan. Pada masa inilah masa penanaman pengalaman gerak yang membekas dalam hidup seorang anak. Partisipasi kegiatan fisik dimasa muda membentuk preverensi untuk aktivitas fisik dimasa tua yang akan datang. Artinya jika masa muda pengalaman fisiknya bagus maka akan secara otomatis dimasa tua keterampilanya juga akan bagus.

Guru pendidikan jasmani mempunyai tugas yang berat dalam mengajar siswa, oleh karena itu diperlukan pengetahuan guru selain mengajar juga mempunyai ilmu pendukung dalam memberikan dasar alasan dalam setiap materi yang diajarkan. Pembelajaran gerak, materi pembelajaran pendidikan jasmani di Sekolah Dasar seharusnya berorientasi pada pengayaan berbagai keterampilan motorik. Proses pembelajaran motorik yang dilakukan akan mempengaruhi keterampilan gerak siswa. Untuk itu penelitian ini memberikan solusi pasti kepada guru pendidikan jasmani Sekolah Dasar khususnya kelas atas, dalam memberi bekal jenis gerak khususnya kemampuan koordinasi. Substansi dari model permainan yang dibuat adalah permainan target yang dirangkum dalam permainan yang manantang dan menyenangkan sesuai dengan substansi karakteristik pertumbuhan dan perkembangan anak Sekolah Dasar kelas atas. Model permainan yang dibuat juga disesuaikan dengan peralatan permainan yang mudah didapatkan, murah dari segi harga, memiliki manfaat sesuai dengan tujuan pembelajaran serta dapat dibuat massal dalam jumlah yang besar. Peserta didik akan merasa senang dalam proses belajarnya jika seorang guru menggunakan alat-alat atau media tersebut dalam wujud yang sederhana. Penggunaan alat yang sederhana dalam hasil produk ini dapat memberikan contoh inspirasi bagi guru 
pendidikan Sekolah Dasar khususnya pada kelas atas.

\section{Perkembangan dan Pertumbuhan Siswa Sekolah Dasar}

Usia siswa Sekolah Dasar merupakan kaategori yang banyak mengalami perubahan, baik mental maupun fisiknya. Masa usia Sekolah Dasar (sekitar 6-12 tahun) merupakan tahapan perkembangan penting bahkan fundamental bagi kesuksesan perkembangan peserta didik selanjutnya (Nufarokah 2009). Tugas seorang guru dituntut memahami dengan benar karakteristik peserta didik, arti belajar dan tujuan kegiatan belajar bagi peserta didik di sekolah.

Karakteristik siswa Sekolah Dasar kelas V dan VI menurut Sukintaka dalam Yudanto (2005) adalah a) pertumbuhan otot lengan dan dan tungkai makin bertambah, b) ada kesadaran mengenai badannya, c) anak lakilaki menguasai permainan kasar, d) pertumbuhan tinggi dan berat badan tidak beda baik, e) kekuatan otot tidak menunjang pertumbuhannya, f) waktu reaksi makin baik, g) perbedaan akibat jenis kelamin makin nyata, h) koordinasi makin baik, i) badan lebih sehat dan kuat, j) tungkai mengalami masa pertumbuhan yang lebih kuat dibandingkan dengan bagian anggota atas, k) perlu diketahui bahwa ada perbedaan kekuatan otot antara keterampilan anak laki-laki dan anak perempuan. Anak-anak memiliki perkembangan karakteristik yang khas dan berbeda pada setiap tahapan. Meskipun demikian, tahapan perkembangan tersebut tidak berdiri sendiri melainkan satu dengan yang lain berkaitan dan saling menentukan.

Sedangkan perkembangan gerak dan fisik siswa Sekolah Dasar menurut Gallahue, et.al, (1998) pertumbuhan gerak pada anak usia 6-10 tahun memiliki karakteristik pertumbuhan gerak dan fisik yaitu, a) pertumbuhan lambat, terutama diakhir periode ini meskipun ada peningkatan tetapi peningkatan tersebut lebih lambat dari periode sebelumnya. b) proporsi tubuh mulai memanjang dengan pertambahan tinggi badan sekitar 5,1-7,6 cm /tahun dan berat badan anatara 1,4-2,7 kg/tahun. c) prinsip pertumbuhan adalah chepalocaudal dan proximodistal, dengan pertumbuhan otot besar lebih dominan dari pada otot kecil. d) pertumbuhan anak putri lebih pesat dari pada anak putra terutama pada akhir fase ini (mendekati fase pubertas). e) rendahnya koordinasi mata-tangan dan mata-kaki yang memperngaruhi lambatnya waktu reaksi anak. f) pada aktifitas bermain anak selalu bersemangat dengan menunjukkan energi yang sangat besar akan tetapi daya tahan yang dimiliki masih rendah sehingga tidak bisa memainkan suatu bentuk permainan dengan intensitas tinggi dengan waktu yang lama. g) pada masa ini anak mulai bisa menguasai gerak dasar yang relatif kompleks atau susah terutama pada akhir fase ini.

Berdasarkan pemahaman dari penjelasan diatas dapat disimpulkan bahwa pada masa usia Sekolah Dasar siswa mengalami banyak perubahan baik secaara perkembangan maupun dalam masa pertumbuhannya. Khusunya dalam hal pembelajran gerak disesuaikan dengan tingkat perkembangan dan pertumbuhan siswa Sekolah Dasar lebih ditekankan melalui kegiatan yang dirangkai dalam aktivitas bermain. Siswa akan mudah mengenal dan dapat menyerap materi gerak dasar tanpa terasa dilakukan dalam aktivitas bermain. Secara khusus karakteristik siswa Sekolah Dasar mempunyai ciri khas antara lain, siswa senang bermain, suka bergerak, suka bekerja secara kelompok, suka melakukan dan memperagakan sesuatu secara 
langsung. Melaui kegiatan yang dimasukkan dalam permainan memungkinkan siswa berpindah atau bergerak dan bekerja atau belajar dalam kelompok, serta memberikan kesempatan kepada siswa untuk terlibat langsung dalam proses pembelajaran. Hal ini sesuai dengan yang diutarakan oleh Sumarsono (2017:74) bahwa aktivitas bermain melalui sarana permainan dapat menunjang pencapaian kemajuan jasmani, sosial dan intelektual.

Setiap perkembangan dan pertumbuhan yang normal maka akan berimplikasi pada perubahan. Menurut Rusman (2012), anak pada usia sekolah dasar (7-11 tahun) berada pada operasi kongkret. Pada masa ini tingkah laku anak yang tampak yaitu: 1) anak selalu menandang dunia secara objektif, bergeser dari aspek situasi ke aspek yang lain secara reflektif dan memandang unsur secara serentak; 2) anak mulai berfikir secara operasional; 3) anak sudah mulai mampu memperguanakan cara berfikir secara operasional utuk mengklasifikan benda-benda; 4) anak sudah mampu membentuk dan menggunakan kerterhubungan aturan-aturan, prinsip alamiah sederhana dan menggunakan prinsip hubungan sebab akibat; 5) anak dapat memahami konsep subtantansi, panjang, lebar, luas dan tinggi serta jenis ukuran lainya. Sedangkan pendapat lain juga disampaikan oleh Pramono (2013) berpendapat bahwa siswa Sekolah Dasar yang berusia dalam rentang 6-12 tahun berdasarkan teori Piaget termasuk ke dalam tahap operasional kongkret (7-11 tahun). Selama ini, cara berfikir siswa masih bersifat kongkrit, maksudnya yaitu siswa belum dapat berfikir tentang hal-hal yang bersifat abstrak. Segala sesuatu yang dipelajari harus nyata/kongkrit mulai hal mudah ke hal yang sulit dan dari hal yang sederhana menuju ke hal yang lebih kompleks.

Siswa yang berada dalam kriteria sekolah dasar kelas atas berada pada masa umur 1012 Tahun. Pada umur ini dalam perkembanganya masuk dalam kriteria fase anak besar. Pada fase anak besar ini menurut (Rahyubi, 2012) dari segi perkembangan motorik usia siswa pada fase besar adalah sebagai berikut: Fase anak besar antara usia 6-12 tahun yang menonjol adalah perkembangan sosial dan intelegensi. Perkembangan kemampuan fisik yang tampak pada masa anak besar atau anak yang berusia 6-12 tahun, selain muncul kekuatan yang juga mulai menguasai apa yang disebut dengan flexibiltas dan keseimnbangan perkembangan kekuatan sendiri merupakan hasil kerja otot yang berupa kemampuan untuk mengangkat, menjinjing, menahan, mendorong atau menarik beban. Semakin besar penampang lintang otot, akan semakin besar pula kekuatan yang dihasilkan dari kerja otot tersebut. Sebaliknya semakin kecil penampang lintangnya akan semakin kecil pula kekuatan yang dihasilkan. Sedangkan perkembangan fleksibilitas merupakan keleluasaan gerak persendian. Kemudian perkembangan keseimbangan setidaknya dapat dibagi menjadi dua, yaitu keseimbangan statis dan keseimbngan dinamis. Keseimbangan statis adalah kemampuan mempertahankan posisi tubuh tertentu untuk tidak bergoyang atau roboh. Juga dapat diistilahkan keseimbangan tubuh pada saat diam. Contoh, berdiri dengan satu kaki, keseimbangan dinamik adalah kemampuan untuk mempertahankan tubuh untuk tidak jatuh pada saat melakukan gerakan atau keseimbangan tubuh pada saat bergerak. Contohnya pada saat berlari, meloncat, melempar, dan semacamnya. Kontrol pada motorik halus atau 
keterampilan koordinasi mata dan tangan mewakili bagian yang memindahkan benda dari tangan, mencoret tembok, mengguntng, menulis dan lain-lain. Kurangnya stimulasi yang berlebihan, ditambah lagi dengan gerakan motorik kasar dan halus yang berkembang secara baik, bisa menyebabkan rusaknya perhatian terhadap lingkungan. Dalam perkembanganya, peserta didik akan selalu mengalami perubahan juga berimplikasi pada karakternya. Proses pembelajaran yang dilakukan guru dalam proses pendidikan juga harus memahami perkembangan tersebut. Guru dituntut untuk memahami betul karakteristik siswanya.

\section{Koordinasi Gerak}

Istilah olahraga menyebutkan bahwa manusia terdiri dari komponen tubuh yang sangat kompleks. Kompleksifitas tubuh manusia dipengaruhi oleh banyak hal diantaranya adalah komponen kebuagaran jasmani setiap manusia. Komponen kebugaran jasmani menurut Irianto (2005: 4) komponen kebugaran yang berhubungan dengan kesehatan memiliki empat komponen dasar yaitu, daya tahan parujantung, kekuatan dan daya tahan otot, kelentukan, dan komposisi tubuh. Empat komponen kebugaran jasmani menunjang performa manusia dalam melakukan aktivitas geraknya. Prestasi olahraga dipengaruhi oleh banyak hal. Diantara komponen yang mempengaruhi adalah komponen biomotor dan komposisi tubuh. Kondisi fisik merupakan satu kesatuan yang utuh dari komponen-komponen yang tidak dapat dipisahkan begitu saja, baik peningkatan maupun pemeliharaannya.

Komponen biomotor koordinasi diperlukan pada cabang olahraga yang memerlukan gerak selaras, serasi dan simultan, sehingga gerak yang dilakukan menjadi efektif, efisien dan mudah. Pengertian koordinasi menurut Husdarta \& Kumaedi (2012:109) koordinasi adalah kemampuan untuk mengatur keserasian gerak bagian-bagian tubuh. Kemampuan ini berhubungan dengan kemampuan kontrol tubuh. Koordinasi adalah kemampuan penggabungan sistem saraf gerak yang terpisah dengan merubahnya menjadi suatu pola gerak yang efisien. Makin komplek suatu gerakan, maka makin tinggi tingkat koordinasinya.

Bompa (1999) menyatakan bahwa koordinasi adalah suatu kemampuan biomotorik yang sangat komplek, saling berhubungan dengan kecepatan, kekuatan, daya tahan, dan kelentukan. Menurut Brian Mac "coordination is the ability to repeatedly execute a sequence of movements smoothly and accurately. This may involve the senses, muscular contractions and joint movements". Pendapat lain disampaikan Sukadiyanto \& Muluk (2010) koordinasi merupakan hasil perpaduan kinerja dari kualitas otot, tulang, dan dan persendian dalam menghasilkan satu gerak yang efektif dan efisien. Berdasar pendapat diatas dapat disimpulkan bahwa koordinasi merupakan kemampuan fisiologis manusia yang menimbulkan gerak efektif dan efisien.

Pengertian koordinasi jika dilihat dari sudut fisiologis, koordinasi gerak (neuromuskuler) meliputi koordinasi intramuskuler dan koordinasi intermuskuler. Pengertian koordinasi dari sudut fisiologis intramuskuler menurut Sukadiyanto \& Muluk (2010) koordinasi intramuskuler adalah kinerja dari seluruh serabut syaraf dan otot dalam setiap kerja otot yang berkontraksi secara maksimum. Orang yang memiliki koordinasi intramuskuler baik adalah akan tepat, serasi, ekonomis dan efektif dalam melakukan gerakan. Sedangkan koordinasi 
intermuskuler adalah pelibatan efektivitas otot-otot yang bekerjasama dalam menampilkan gerakan. Kecenderungan selama ini koordinasi diartikan sebagai kemampuan seseorang untuk merangkai beberapa unsur gerakan menjadi suatu gerakan yang selaras sesuai dengan tujuannya.

Berdasar pendapat di atas dapat disimpulkan gerak koordinasi adalah kemampuan seseorang untuk merangkai beberapa unsur gerak menjadi satu gerakan yang selaras sesuai dengan tujuannya. Koordinasi merupakan kemampuan untuk menyelesaikan tugas motorik secara cepat dan terarah yang ditentukan oleh proses pengendalian dan pengaturan gerakan serta kerjasama sistem persyarafan pusat. Oleh karena itu perlu dihimpun suatu tenaga dengan mengkoordinasikan tenaga-tenaga dari alat-alat gerak atau bagian-bagian tubuh yang lain. Penggunaan tenaga yang cukup besar tersebut dimulai dari alat gerak atau bagian tubuh tertentu yang diteruskan ke bagian-bagian tubuh yang lain yang membantu pembangunan tenaga yang cukup besar, kemudian dikoordinasikan dan dihimpun serta disalurkan ke otot-otot. Spesifikasi dari komponen biomotor yang dilibatkan dalam variabel penelitian ini adalah komponen koordinasi gerak yang diakomodasi dalam kegiatan pembelajaran pendidikan jasmani.

\section{Permainan Target}

Cakupan pengembangan dalam dalam penelitian ini adalah permainan target. Dua kata dalam permainan target terdiri dari kata permainan dan kata target. Pengertian permainan menurut Mumpuniarti (2003) adalah aktivitas rekreasi yang melibatkan peran-peran yang pasti dan melibatkan kompetisi atau kerjasama beberapa orang atau lebih. Sementara itu, menurut Cristohper \& Ludy (2009): "Basic game is single every human instinct to compete and archieve a science of statisfaction that complex, the basis of this game is also used to reach and encourage the development and introduction of the sport".

Jika diartikan kurang lebihnya sebagai berikut dasar permainan adalah naluri tunggal setiap manusia untuk besaing dan mencapai kepuasan naluri yang komplek, dasar dari permainan ini juga digunakan untuk mencapai dan menyemangati pengembangan dan pengenalan olahraga. Berdasar dari pengertian permainan tersebut tadi dapat disimpulkan bahwa yang dimaksud dengan permainan adalah sarana yang dilakukan untuk aktivitas bermain, didalamnya terdapat peraturan yang sudah di sepakati oleh anggota yang melakukan aktivitas bermain tersebut. Sedangkan pengertian dari target adalah permainan yang menggunakan target sebagai sasaran.

Permainan target menurut Mitchell et al. (2003) ialah permainan yang dimana pemain akan mendapatkan skor apabila bola atau proyektil lain sejenis baik dilempar atau dipukul dengan terarah mencapai sasaran yang sudah ditentukan dan semakin sedikit untuk menuju pukulan atau perlakuan menuju sasaran semakin baik. Permainan yang dilakukan dalam penelitian ini, menggunakan menggunakan target yag tidak digunakan untuk permainan penuh, akan tetapi permainan hanya digunakan sebagai sarana untuk menggunakan kontrol anggota tubuh. Bergerak kekiri dan kekanan menggunakan target sebagai sarana meningkatkan koordinasi siswa. 


\section{MATERI DAN METODE}

\section{Jenis Penelitian}

Penelitian ini adalah penelitian dan pengembangan. Prosedur pengembangan dan penelitian ini mengadaptasi langkahlangkah pengembangan pendidikan yang dikembangkan oleh Walter Dick \& Lou Carey, secara detailnya dapat dijelaskan dalam gambar 1 .

\section{Waktu dan Tempat Penelitian}

Penelitian dan pengembangan ini dilakukan pada bulan September sampai dengan November 207. Tempat penelitian sebagai tempat uji coba digunakan 3 sekolah dasar yakni SD YPK Ermasu Merauke, SD Wasur 1 Merauke, dan SD Inpres Gudang Arang Merauke.

\section{Target/Subjek Penelitian}

Subjek penelitian uji coba produk dilakukan di SD YPK Ermasu Merauke, SD Wasur 1 Merauke, dan SD Inpres Gudang Arang Merauke. Adapun ahli yang dilibatkan dalam pengembangan ini meliputi ahli permainan, ahli pembelajaran pendidikan jasmani, ahli pendidikan jasmani usia dini dan praktisi atau guru yang mengajar di Sekolah Dasar. Spesifikasi produk yang dikembangkan adalah produk berupa video model pembelajaran yang berasal dari pengembangan berupa model permainan target untuk meningkatkan kemampuan koordinasi pada siswa Sekolah Dasar kelas atas. Model permainan dibuat dengan konsep permainan yang menyenangkan, pemakaian alat yang mudah ditemui dalam kehidupan sehari-hari serta penyesuaian alat yang aman untuk aktifitas bermain. Model permainan target yang dibuat mengandung faktor pembelajaran kemampuan koordinasi yang terdiri dari pengenalan perasaan terhadap objek, mengontrol objek, keseimbangan mereaksi dan akurasi terhadap objek.

\section{Prosedur Penelitian}

Prosedur penelitian yang dilakukan dapat digambarkan pada Gambar 1.

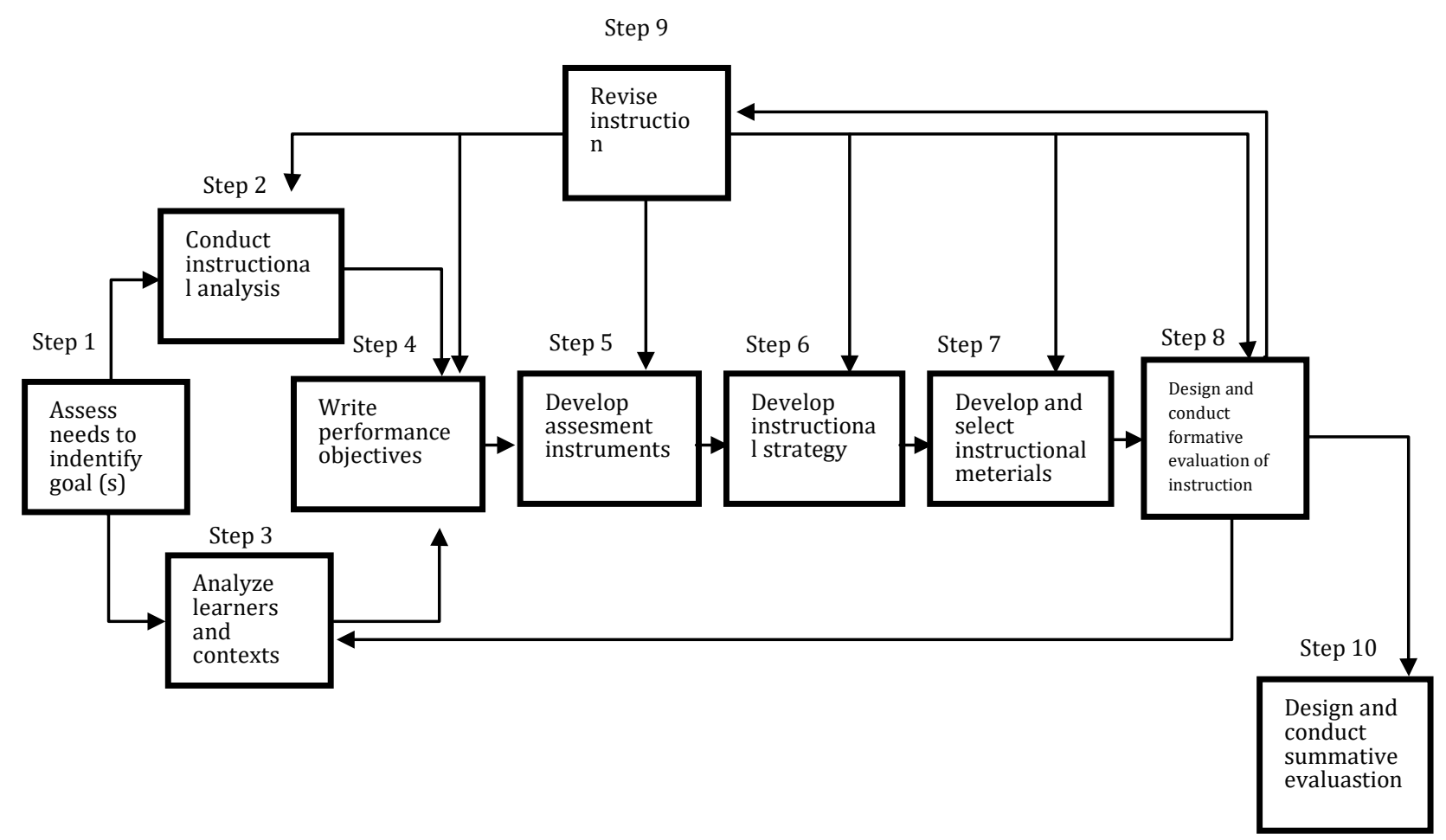

Gambar 1 Skema prosedur penelitian dan pengembangan (Dick \& Carey, 2005) 
Penelitian pengembangan model permainan target untuk meningkatkan kemampuan koordinasi pada siswa Sekolah Dasar kelas atas mengadapatasi langkahlangkah pengembangan. Adapun tujuan utama dari pembuatan produk ini adalah membuat model pembelajaran yang menyenangkan serta efektif digunakan untuk proses pembelajaran. Berdasar pada sumber pengembangan model Dick \& Carey (2005) dapat dijelaskan penyederhanaan/adaptasi sesuai dengan keadaan saat di lapangan. Keadaan penelitian yang dimaksud adalah terbatasnya dana, waktu dan kesempatan dalam melakukan penelitian. Prosedur pengembangan pada penelitian ini disesuaikan pada langkah yang diadaptasi dari pendapat Dick \& Carey (2005), yaitu pengumpulan data tentang informasi lapangan, melakukan analisis informasi lapangan, pengembangan produk awal sesuai dengan kebutuhan di lapangan, di dalam pembuatan produk awal di validasi oleh ahli.

\section{Data, Instrumen, dan Teknik Pengumpulan Data}

Metode pengumpulan data dalam penelitian ini adalah dengan cara observasi terhadap model permainan yang dibuat. Intrumen yang digunakan dalam pengumpulan data menggunakan angket. Angket digunakan untuk mengukur antara kesesuaian model, ketercapaian model sesuai dengan tujuan serta implementasi lapangan yang direncanakan. Ahli yang dilibatkan pada penelitian dan pengembangan ini meliputi ahli pendidikan jasamani, ahli permainan, ahli olahraga usia dini dan praktisi atau guru sekolah. Selain dari angket dari ahli juga dilakukan studi wawancara kepada siswa tentang pendapatnya menganai pelaku dalam subyek yang dilakukan model.

\section{Teknik Analisis Data}

Analisis data yang digunakan dalam penelitian ini menggunakan pada skor yang diperoleh dari kegiatan uji coba produk. Data di peroleh melalui kegiatan uji coba produk. Kegiatan uji coba diklasifikasikan menjadi dua, yaitu data kuantitif dan kualitatif. Data kualitatif berupa penilaian, kritik dan saran yang dikemukakan oleh ahli, dari saran dan kritik yang diberikan kemudian dihimpun untuk kegunaan perbaikan permainan yang sedang dikembangkan melalui pembelajaran yang dihasilkan. Teknik analisis data kuantitatif dalam penelitian ini menggunakan analisis statistik deskriptif, yang berupa pertanyaan sangat kurang, kurang, cukup, baik, sangat baik yang diubah menjadi data kuantitatif dengan skala 5 yaitu dengan pengskoran dari angka 1 s/d 5. Langkah-langkah dalam analisis data antara lain: (a) mengumpulkan data kasar, (b) pemberian skor, (c) skor yang diperoleh kemudian dikonversikan menjadi nilai dengan skala 5 dengan menggunakan acuan konversi dari Sukardjo (2005).

\section{HASIL DAN PEMBAHASAN}

Kegiatan penelitian dan pengembangan yang dilakukan berdasar rangkaian tahap pengembangan dapat dijelaskan bahwa hasil analisis dari studi awal yang dilakukan di Sekolah Dasar terkait diperoleh informasi, diantaranya sebagai berikut. Pertama, sesuai dengan kompetensi dasar kelas atas yaitu mempraktekan gerak dasar dan permainan sederhana dengan peraturan yang dimodifikasi serta nilai kerjasama sportivitas dan kejujuran, dan sesuai indikator pencapaian kompetensi pada siswa kelas atas adalah dapat melakukan gerak fundamental yaitu 
lokomotor, non lokomotor dan manipulatif, akan tetapi sesuai dengan hasil observasi didapatkan fakta lapangan bahwa permainan yang diajarkan oleh guru ditanggapi siswa kurang antusias. Berdasar wawancara kepada siswa bahwa permainan kurang variatif dan cenderung monoton karena yang diajarkan dari kelas atas adalah permainan itu-itu saja. Rangkaian gerak yang didalamnya permainan hanya sebatas teknik dan tidak menarik.

Kedua, kemampuan guru dalam mengekplorasi permainan membutuhkan model pembelajaran yang beragam, akan tetapi guru kesulitan dalam mendapatkan panduan model permainan yang baku. Harapanya guru dapat dibantu dengan adanya model yang berupa Video bergerak yang dapat memberikan inspirasi pembelajaran yang beragam. Ketiga, keadaan sarana dan prasarana yang ada di Sekolah Dasar sangat terbatas. Dibuktikan dengan alat yang tersedia di sekolah dalam pembelajaran pendidikan jasmani khususnya permainan hampir tidak ada, jika pun ada hanya peraltan olahraga standart yang digunakan dalam pertandingan antar sekolah.

Berdasar hasil analisis kebutuhan di atas, maka dapat diindikasikan bahwa diperlukan suatu model permainan yang dapat mengakomodasi kebutuhan di lapangan terutama bagi guru dalam melaksanakan pembelajaran permainan target yang dapat meningkatkan keterampilan koordinasi siswa berdasar pada tujuan kurikulum yang berlaku, fokus tujuan pengembangan meliputi aspek kognitif, efektif dan psikomotor siswa. Model permainan disusun memperhatikan aturan keselamatan siswa, peraturan permainan yang jelas dan lingkup permainan yang menantang dan menyenangkan. Dari hasil model permainan yang dihasilkan diharapkan:

a) menambah variasi baru dalam proses pembelajaran koordinasi keterampilan gerak siswa di Sekolah Dasar kelas atas.

b) memotifasi guru dalam memanfaatkan sarana dan prasarana yang ada.

c) membantu guru dalam menyelenggarakan pembelajaran permainan di lingkup Sekolah Dasar kelas atas.

d) dapat merangsang kemauan guru dalam mengajar menggunakan fasilitas prasarana yang dapat dimodifikasi sehingga terlihat antusias siswa dalam bekal kreativitasnya.

Produk awal yang dikembangkan dalam penelitian ini berdasar dari studi pendahuluan yang diperlukan guru Sekolah Dasar khususnya kelas atas. Produk awal yang dikembangkan berupa permainan target yang digunakan untuk meningkatkan kemempuan koordinasi siswa. Model permainan dibuat sedemikian menyenangkan dan memberi efek gerak dasar yang dilakukan untuk meningkatkan kemampuan koordinasi. Adapun nama dan spesifikasi model permainan target yang dikembangkan untuk meningkatkan kemampuan koordinasi siswa Sekolah Dasar kelas atas sesuai di Tabel 1.

Semua model permainan target dibuat dengan mengacu pada teori kemampuan biomotor manusia yaitu kemampuan koordinasi. Model permainan disesuaikan dengan kegiatan pembelajaran pendidikan jasmani di Sekolah Dasar kelas atas. Pedoman dalam membuat alat yaitu mudah, murah, manfaat dan dapat dibuat massal. 
Tabel 1 Kisi-kisi model permainan target

\begin{tabular}{ll}
\hline \multicolumn{1}{c}{ Nama Model } & \multicolumn{1}{c}{ Bentuk aktivitas } \\
\hline Model permainan & Permainan \\
target & dilakukan sendiri \\
menggelindingkan & Permainan \\
& dilakukan dengan \\
& alat \\
& Permainan \\
& dilakukan dengan \\
& berpasangan \\
Model permainan & Permainan \\
target & dilakukan sendiri \\
memantulkan & Permainan \\
& dilakukan dengan \\
& alat \\
& Permainan \\
& dilakukan dengan \\
& berpasangan \\
& Permainan \\
Model permainan & dilakukan sendiri \\
melempar & Permainan \\
& dilakukan dengan \\
& alat \\
& Permainan \\
& dilakukan \\
& berpasangan \\
\hline
\end{tabular}

\section{Data Hasil Observasi Permainan Target Menggelindingkan}

Permainan target dengan metode menggelindingkan dan selanjutnya dilakukan observasi melalui tiga ahli dan satu orang praktisi. Adapun hasil dari observasi pada uji coba dapat dilihat pada gambar 2.

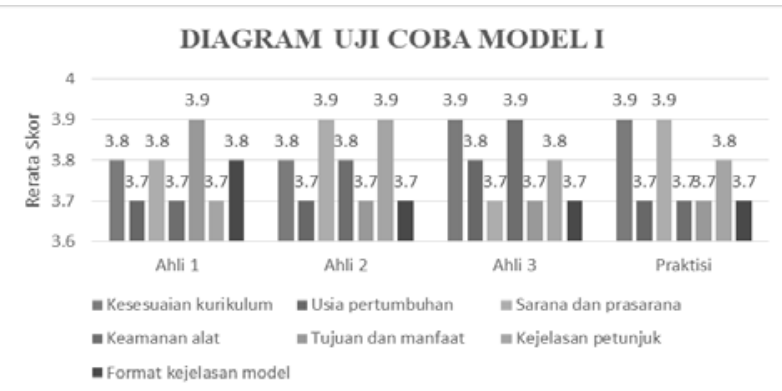

Gambar 2 Observasi uji coba model permainan menggelindingkan
Hasil uji observasi uji coba model berdasar penjelasan data dan dijelaskan melalui gambar 2. maka dapat disimpulkan bahwa permainan target menggelindingkan bola masuk dalam kategori baik. Adapun gambaran dari permainan target menggelindingkan bola dapat dilihat gambar 3 dan gambar 4 .

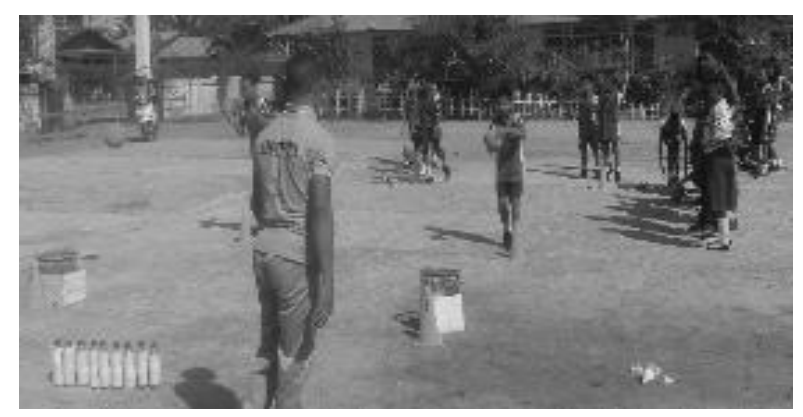

Gambar 3 Menggelindingkan bola

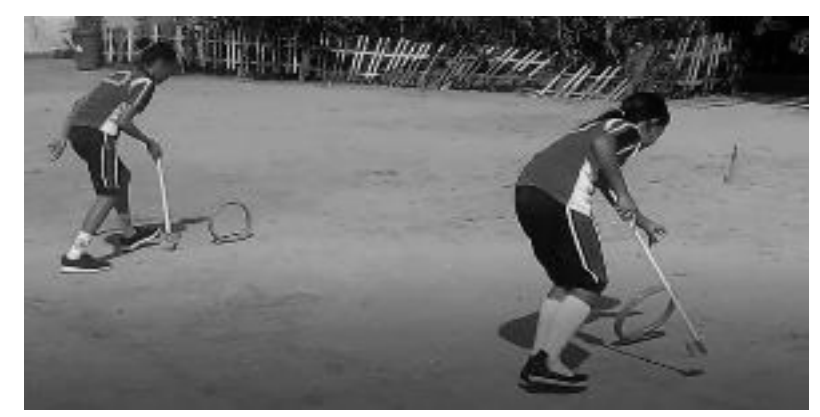

Gambar 4 Menggelindingkan roda dorong

\section{Data Hasil Observasi Permainan Target Memantulkan Bola}

Observasi dilakukan permainan target dengan metode memantulkan bola dan selanjutnya dilakukan melalui tiga ahli dan satu praktisi. Adapun hasil dari observasi pada uji coba dapat dilihat pada gambar 5 .

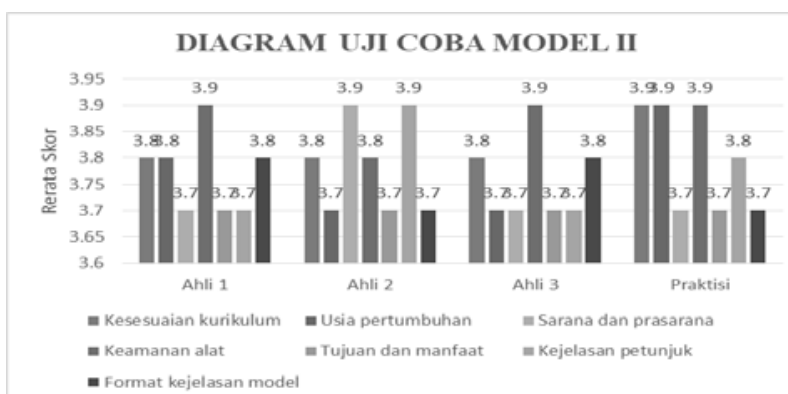

Gambar 5 Observasi uji coba permainan target memantulkan 
Hasil observasi uji coba model berdasar penjelasan data dan dijelaskan melalui gambar 5 maka dapat disimpulkan bahwa permainan target memantulkan masuk dalam kategori baik. Adapun gambaran dari permainan target memantulkan dapat dilihat pada gambar 6 dan gambar 7 .

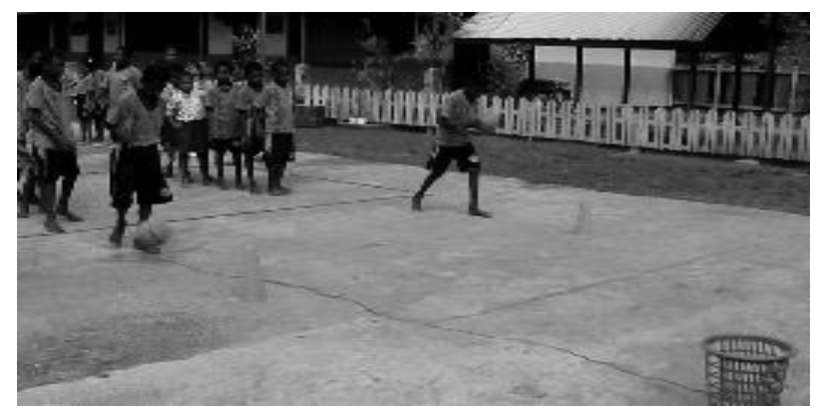

Gambar 6 Memantulkan tanpa alat

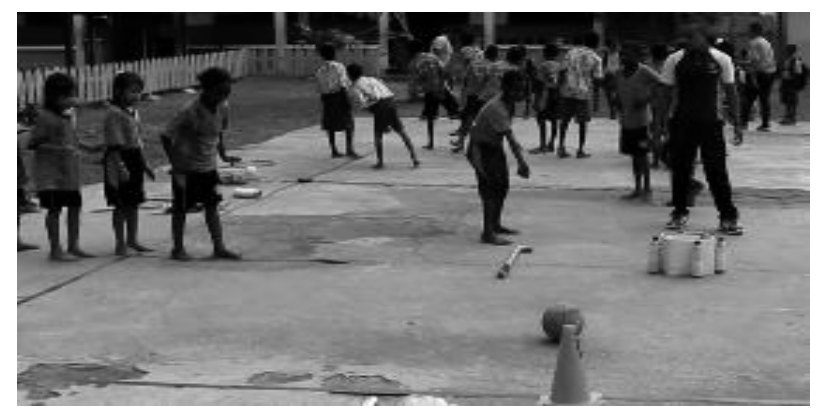

Gambar 7 Memantulkan dengan alat

\section{Data Hasil Observasi Permainan Target Melemparkan}

Observasi dilakukan permainan target dengan metode melemparkan bola dan melemparkan ring yang terbuat dari slang air yang dimodivikasi. Dalam kegiatan permainan target melempar terdiri dari tanpa menggunakan alat dan tanpa menggunakan alat. Hasil dari model selanjutnya dilakukan analisis yang dilakukan oleh tiga ahli dan satu praktisi. Adapun hasil dari observasi pada uji coba dapat dilihat pada gambar 8 .

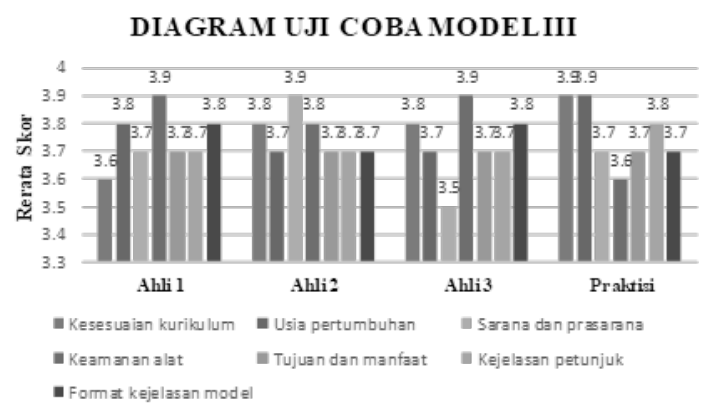

Gambar 8 Hasil observasi uji coba permainan target melemparkan

Hasil uji observasi uji coba model berdasar penjelasan data dan dijelaskan melalui gambar maka dapat disimpulkan bahwa permainan target melemparkan masuk dalam kategori baik. Adapun gambaran dari permainan target melemparkan dapat dilihat pada gambar 9 dan gambar 10 .

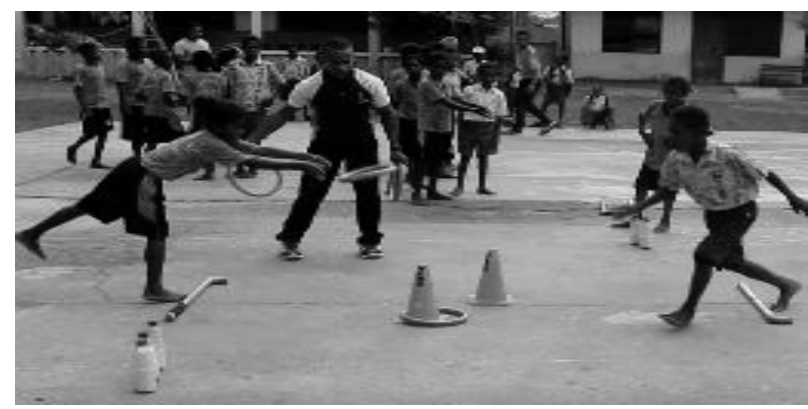

Gambar 9 Melempar tanpa alat

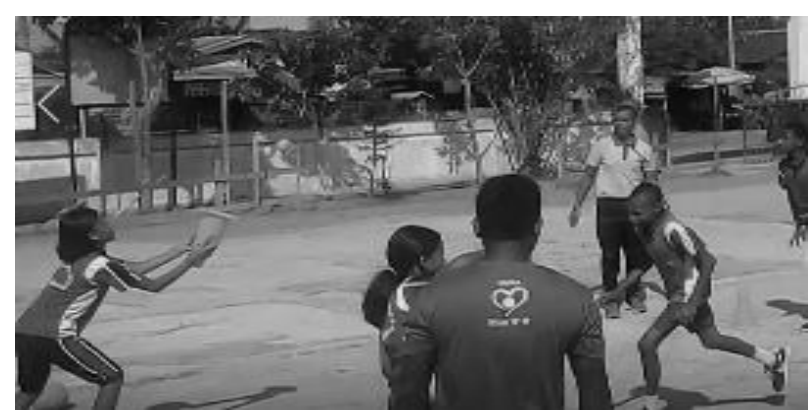

Gambar 10 Menangkap dengan alat

Selain hasil observasi yang dilakukan juga mendapatkan masukan dari para ahli terhadap model permainan target, yang dijelaskan pada tabel 2 . 
Tabel 2 Data masukan tentang model dari para ahli

\begin{tabular}{|c|c|}
\hline $\begin{array}{c}\text { Ahli materi } \\
\text { dan } \\
\text { praktisi }\end{array}$ & Isi masukan dan perbaikan \\
\hline $\begin{array}{l}\text { Ahli } \\
\text { permainan }\end{array}$ & $\begin{array}{l}\text { Penyesuaian alat dan } \\
\text { lapangan sekolah, } \\
\text { pertimbangan karena } \\
\text { masih ada sekolah yang } \\
\text { belum mempunyai } \\
\text { lapangan yang padat dan } \\
\text { permanen. Masih ada } \\
\text { sekolah yang mempunyai } \\
\text { lapangan rumput. }\end{array}$ \\
\hline $\begin{array}{l}\text { Ahli } \\
\text { pendidikan } \\
\text { jasmani }\end{array}$ & $\begin{array}{l}\text { Kegiatan gerak yang ada } \\
\text { dalam permainan harus } \\
\text { mengedepankan gerak } \\
\text { setiap siswa. } \\
\text { Untuk jenis permainan } \\
\text { pada masing-masing } \\
\text { bagian sebaiknya } \\
\text { dihilangkan permainan } \\
\text { yang berpasangan, } \\
\text { dikarenakan tidak } \\
\text { menggambarkan } \\
\text { koordinasi gerak secara } \\
\text { individu. }\end{array}$ \\
\hline $\begin{array}{l}\text { Praktisi / } \\
\text { Guru kelas }\end{array}$ & $\begin{array}{l}\text { Acuan kurikulum yang } \\
\text { digunakan setiap sekolah } \\
\text { wajib digunakan sebagai } \\
\text { acuan pembuatan model, } \\
\text { siswa dan siswi wajib } \\
\text { melakukan tugas gerak } \\
\text { yang sama dalam } \\
\text { pembelajaran, model yang } \\
\text { digunakan dalam proses } \\
\text { pembelajaran harus sesuai } \\
\text { dengan siswa Sekolah } \\
\text { Dasar kelas atas. }\end{array}$ \\
\hline
\end{tabular}

Setelah mendapatkan saran guna perbaikan model dapat disimpulkan sebagai berikut. Pertama, model permainan target dengan menggelindingkan. Dilakukan dengan pertimbangan koordinasi yang mudah dimengerti oleh siswa. Revisi yang dilakukan dengan pengaturan siswa sesuai dengan jumlah siswa dilapangan. Gerakan koordinasi tangan dan mata dapat dijelaskan dengan terperinci. Siswa lebih dominan dalam permainan, karena asyik bermain maka peraturan harus tegas, untuk jenis permainan menggelindingkan berpasangan dihilangkan sesuai dengan saran ahli. Kedua, model permainan target dengan memantulkan. Revisi yang dilakukan dalam permainan memantulkan hanya pertimbangan lapangan yang dapat memantulkan. Arah pantulan dan koordinasi gerakan semakin lama semakin sulit dan menantang, tambahan variasi pembelajaran dengan dilombakan akan menambah keseruan dan permainan lebih menyenangkan. Jenis permainan memantulkan dengan berpasangan dihilangkan sesuai saran dari ahli. Ketiga, model permainan target dengan melempar. Revisi yang dilakukan dalam pengembangan ini adalah faktor keselamatan siswa dalam melakukan gerakan melempar. Bola dan sarana yang digunakan dalam permainan harus terbuat dari bahan yang aman tanpa mengurangi fungsi dari permainan. Jenis permainan dengan melempar yang berpasangan disesuaikan dengan keadaan siswa. Materi lempar ditambahkan dengan kesulitan menangkap bola menggunakan cone

Berdasarkan masukan dan dilakukan perbaikan model, selanjutnya dilakukan pembuatan produk akhir. Pembuatan produk akhir dilakukan berdasarkan data masukan dan pernbaikan saran yang telah disarankan oleh para ahli. Adapun model yang dihasilkan dari produk pengembangan ini adalah sebagai berikut: (1) model pengembangan terdiri dari tujuh kegiatan permainan yang dibuat dalam satu video 
pembelajaran dan disimpan dalam bentuk VCD, (2) pemeran model dalam pengembangan ini adalah siswa Sekolah Dasar yang dilibatkan dalam penelitian, (3) model yang dibuat sesuai dengan kajian teori tentang pengembangan gerak dasar biomotor yang disesuaikan dengan kurikulum Sekolah Dasar, (4) model yang dibuat menyesuaikan dengan kebutuhan guru, tata cara, alat dan peraturan alat dimodifikasi oleh guru sesuai dengan keadaan sekolah, (5) produk pengembangan disesuaikan cocok dengan pelajaran tematik yang ada di Sekolah Dasar, dan (6) kemasan merupakan hal yang sangat menarik perhatian pengguna, untuk itu kemasan produk VCD dibuat sedemikian rupa sehingga keinginan dan maksud pembuat produk dapat tersampaikan. Berikut ini tampilan cover muka produk ini.

Hasil dari implementasi model permainan target untuk meningkatkan kemampuan koordinasi terbukti berhasil. Walaupun secara implementasi dari produk akhir yang dihasilkan belum dilaksanakan akan tetapi berdasar pada uji coba produk dilapangan khususnya Pada Siswa Sekolah Dasar, membuktikan bahwa permainan sangat di senangi dalam bentuk aktivitas fisik oleh siswa. Hal ini sesuai dengan hasil penelitian....yang mengatakan bahwa 100\% siswa usia sekolah dasar sangat suka permainan. Permainan koordinasi gerak sesuaia diberikan pada usia anak sekolah hal ini dibenarkan pendapat Sukadiyanto (2006) bahwa faktor kemampuan koordinasi sebagai salah satu parameter kemampuan motorik pada anak usia Sekolah Dasar, dan merupakan jenis kemampuan yang mendasari dalam belajar berbagai keterampilan gerak (motorik). Oleh karena itu kemampuan koordinasi sangatlah penting diajarkan dan di berikan stimulasi di masa awal sekolah. Jika dalam gerakan dalam aktivitas jasmani maka diberikan stimulasi melalui pendidikan yang ada disekolah sedini mungkin hal ini yang dimaksud dengan tingkatan sekolah sedini mungkin adalah berada dalam pendidikan formal di Sekolah Dasar.

\section{KESIMPULAN DAN IMPLIKASI}

\section{Kesimpulan}

Berdasarkan hasil penelitian dan pengembangan yang dilakukan dihasilkan produk berupa model permainan yang dapat diaplikasikan pada materi permainan pendidikan jasmani Sekolah Dasar kelas atas. Materi permainan yang disimpan dalam bentuk Video (VCD) yang layak digunakan sebagai alternatif pembelajaran pendidikan jasmani. Berdasar analisis data dari ahli model permainan target diperoleh rerata skor yang masuk dalam kategori layak. Berdasarkan hasil validasi kualitas permainan target, diperoleh hasil bahwa permainan target yang dikembangkan masuk dalam kategori "baik" dengan rerata sedangkan penilaian siswa secara keseluruhan adalah "sangat baik". Tanggapan siswa terhadap permainan permainan target sangat antusias, senang dan menggembirakan. Siswa dapat sarana dan model permainan yang berbeda dengan pembelajaran biasanya. Sedangkan pendapat guru dalam mengimplementasikan model dapat berjalan dengan baik dan bekerjasama.

\section{Implikasi}

Berdasar kesimpulan yang telah dibuat, Implikasi dari hasil penelitian ini sangat berguna untuk perbaikan dan memberikan khasanah model pembelajaran pendidikan jasmani bagi siswa Sekolah Dasar. Guru dapat menggunakan model ini sebagai 
patokan permainan ataupun inspirasi baru dalam menambah khasanah pembelajaran. Secara khusus implikasi dari hasil penelitian ini adalah, Bagi Sekolah, 1) Produk yang dihasilkan dari penelitan pengembangan ini sesuai dengan karakteristik siswa SD kelas atas, sehingga sekolah dapat mengaplikasikan dalam proses pembelajaran pendidikan jasmani. 2) Sekolah dapat memfasilitasi guru dalam mengimplemtasikan model permainan yang dilakukan oleh guru pendidikan jasmani. Bagi Guru, 1) Produk model permainan diperuntukkan kepada guru sebagai pemakai model pembelajaran. 2) Model permainan yang digunakan dalam pembelajran pendidikan jasmani dapat diaplikasikan dalam pembelajaran pendidikan jasmani siswa SD kelas atas. 3) Guru sebagai pemakai produk ini dapat mempelajarinya dengan melihat Video yang disimpan dalam bentuk VCD. 4) Bagi guru pendidikan jasmani SD kelas atas sebagai pemakai produk pengembangan ini diharapkan dapat mengembangkan permainan sesuai dengan kreatifitas masing-masing yang tentunya menyesuaikan dengan karakteristik siswa dan keadaan lingkungan sekolah sekitar. Bagi siswa 1) Dengan diterapkan model permainan ini diharapkan dapat memberikan kreatifitas gerak yang sesuai dengan tujuan dan karakteristik ketrampilan gerak. 2) Siswa yang sudah terampil dalam gerak dapat menggunakan dalam permainan olahraga yang memerlukan keterampilan gerak yang kompleks.

\section{DAFTAR PUSTAKA}

Bompa, T. O., \& Haff, G. G. (2009). Periodezation: teory and methodology of training (5thed). USA: Human Kinetics.
Cristohper, \& Ludy. (2009). Psychology Gets in the Game: sport, mind, and behavior. Londan: Nesbraka.

Dick, W., Carey, L., \& Carey, J. O. (2005). The systematic design of instruction. Boston: MA:Allyn and Bacon.

Gani, R. A. (2016). Implementasi Pembelajaran Keterampilan Gerak dalam Pendidikan Jasmani dan Ilmu Keolahragaan. Seminar Nasional Keolahragaan Refleksi prestasi dan Budaya Olahraga dalam perspektif Ilmu Keolahragaan yang Inovatif (hal. 401). Yogyakarta: UNY Press.

Husdarta, \& Kumaedi. (2012). Pertumbuhan dan perkembangan peserta didik olahraga dan kesehatan. Bandung: Alfabeta.

Irianto, D. P. (2005). Pedoman praktis berolahraga untuk kebugaran dan kesehatan. Yogyakarta: Andi Offset.

Mumpuniarti. (2003). Penanganan anak tuna grahita (kajian dari segi pendidikan, social-psikologis dan tindak lanjut usia dewasa. Yogyakarta: FIP UNY Press.

Rahyubi, H. (2012). Teori-Teori Belajar dan Aplikasi Pembelajran Motorik Deskripsi dan Tunjauan Kritis. Bandung: Nusa Media.

Rusman. (2012). Model-model pembelajaran mengembangkan profesionalisme guru. Jakarta: Raja Grafindo Persada.

Sukadiyanto. (2006). Peranan latihan visualisasi dalam permainan tenis. Jurnal Olahraga Majalah Ilmiah, 14.

Sukadiyanto, \& Muluk, D. (2010). Pengantar teori dan metodologi melatih fisik. Bandung: CV. Lubuk Agung.

Sukardjo. (2005). Evaluasi pembelajaran semester 2. Yogyakarta: PPs UNY.

Sumarsono, A. (2015). Pengembangan Model permainan Pengenalan Hoki sebagai Pembelajaran Pendidikan Jasmani Bagi Siswa Sekolah Dasar kelas Atas. Yogyakarta: Thesis PPS UNY. 
Sumarsono, A. (2017). Implementasi Model Pembelajaran Atletik Melalui Permainan Berbasis Alam. Jurnal Magistra, 71.

Sumarsono, A. (2017). Perbedaan Kebugaran Kardiorespirasi Mahasiswa Jurusan Penjaskesrek Tahun 2013 Dan Tahun 2016 Universitas Musamus. Jurnal Magistra, 4(1): 16.

Sumarsono, A., Santo, Z., \& Hidayat, A. K. (2017). Pengembangan Model Pembelajaran Atletik Melalui Permainan Berbasis Alam pada Sekolah Dasar
Daerah Perbatasan RI-PNG. Seminar Nasional Kependidikan Inovasi pendidikan dan pembelajaran dalam rangka percepatan pembangunan didaerah pinggiran (hal. 28). Merauke: Fakultas Keguruan dan Ilmu Pendidikan, Universitas Musamus Merauke.

Yudanto. (2005). Pengembangan gerak dasar lari dan lompat melalui pendekatan bermain di Sekolah Dasar. Jurnal Pendidikan Jasmani Indonesia, 3(1): 72. 